Article

\title{
Revisiting the "City Life Cycle": Global Urbanization and Implications for Regional Development
}

\author{
Sirio Cividino ${ }^{1}$, Rares Halbac-Cotoara-Zamfir ${ }^{2, *}$ and Luca Salvati ${ }^{3,4}$ \\ 1 Department of Agriculture, University of Udine, Via del Cotonificio 114, I-33100 Udine, Italy; \\ civsirio@tiscali.it \\ 2 Department of Overland Communication Ways, Foundation and Cadastral Survey, Politehnica University of \\ Timisoara, 1A I. Curea Street, 300224 Timisoara, Romania \\ 3 Council for Agricultural Research and Economics (CREA), Viale S. Margherita 80, I-52100 Arezzo, Italy; \\ luca.salvati@crea.gov.it \\ 4 Global Change Research Institute of the Czech Academy of Sciences, Lipová 9, CZ-37005 České Budějovice, \\ Czech Republic \\ * Correspondence: raresh_81@yahoo.com; Tel.: +40-727315750
}

Received: 20 January 2020; Accepted: 3 February 2020; Published: 5 February 2020

\begin{abstract}
A comparative, diachronic analysis of urban population dynamics allows for the identification of specific demographic trajectories influencing metropolitan expansion worldwide. However, a wide-ranging characterization of long-term population trends in metropolitan areas identifying sequential urban cycles with distinctive demographic dynamics is still incomplete. By hypothesizing a trade-off between 'fast' and 'slow' population dynamics that reflect 'high' and 'low' fertility regimes in both advanced and emerging economies, the present work investigates the relationship between city size (considering absolute population) and population growth rate in 1857 metropolitan agglomerations (>300,000 inhabitants in 2014) of 154 countries across the globe. Analysis covers a relatively long time period (1950-2030) and uses descriptive statistics (average and coefficient of variation) of the spatial series of population growth rates derived from United Nations demographics by metropolitan agglomeration and time interval. The results of our study indicate that metropolitan growth was associated with highly variable rates of population growth, being highly positive before 2000 and declining progressively in the subsequent decades. Despite important differences at the regional scale, an inverse relationship between population growth and city size was observed up to the late 1990s, with a higher spatial heterogeneity reflecting a moderate slowdown in demographic dynamics during recent years. Rapid population expansion dependent on city size and a higher spatial heterogeneity in growth rates insensitive to city size, evidence distinct metropolitan cycles reflecting worldwide transition from high to low fertility, ageing, and more unpredictable migration patterns.
\end{abstract}

Keywords: population trends; urban growth; global cities; world population statistics; metropolization

\section{Introduction}

Continuous urbanization has occurred in the last century and is still evolving under the differential influence of population growth and migration [1-5]. Long-term population growth reflects socioeconomic transformations better than other territorial factors and processes [6-9]. Urban expansion has been of long-standing interest to social science because of the association of urbanization and demographic change with economic growth [10-13]. Short and long-term changes in population growth at both local and regional scales were considered to identify metropolitan life cycles, defined as 
a time interval with consolidation and decline of a specific urban phase with a (more or less) clear linkage with demographic dynamics, social trends and economic performances [14-16].

Ambiguity in the definition of sequential urban cycles was traditionally motivated by the fact that a multitude of factors co-operate at different spatial scales, leading to new urban transformations [17-19]. At the same time, settlement expansion was progressively decoupled from population growth - with the former advancing more rapidly than the latter-questioning the overall sustainability of contemporary urban systems [20-22]. Relative city growth gives indication on demographic shifts at both local and regional scale likely better than more accurate indicators in a spatially implicit context [23-25]. Analysis of urban growth by size class of towns would also contribute to understanding the stages of metropolitan development in a given country [26-29]. Differential growth rates indicate the extent of (internal and international) migration, and local changes in fertility and mortality rates [30-32].

City size (considering the absolute number of population at a given time point) is also regarded as an important attribute influencing population growth [33]. Given the increased role of urban regions in a globalized economy [34], it is expected that bigger cities will grow faster than smaller ones [35], but this has been not found true in some cases [36]. More specifically, small towns are expected to grow slowly compared to larger cities in the early phases of urbanization [37]. During late urbanization, small towns are expected to grow more as a result of congestion and crowding in large and intermediate towns [38]. However, other studies found that cities of different sizes grow at similar rates [39].

Time-series approaches in which present size is determined by past size are proposed with the aim to explain city growth dynamics [27]. Being intrinsically linked with urban life cycle theories, Gibrat's law was frequently applied to city size and population growth rate, by hypothesizing that no regular behaviour of any kind can be inferred between population growth rate and the initial size of cities [40]. Mixed evidence in favour of a Gibrat's law relating the population growth rate to city size was proposed. In this regard, it was supposed that larger cities attract and maintain (political and economic) hegemonic roles within national, continental or even world (urban) hierarchy. However, other works indicate spatial patterns in contrast with the Gibrat's law, i.e., a negative relationship between city size and population growth rate, under the assumption that scale effects matter, i.e., the growth rate of the biggest cities has less variance than the smallest ones [41]. This implies that smaller cities may frequently grow faster than larger cities [28,35,42].

Unfortunately, cyclical urbanization models-often incorporating the predictions of Gibrat's law-reflect only partly the complex dynamics of worldwide urban development. While urbanization has traditionally been understood as a by-product of economic development [43], this explanatory framework fails to account for more specific phenomena, including "urbanization without economic growth" observed in developing regions of the world and, less frequently, in some developed countries. Under the assumption that metropolitan expansion is basically fuelled by population growth [27], empirical evidence outlines the increasing importance of the 'demographic dimension' of urban growth and the intimate linkage with more general processes, including - but not limited to - the second demographic transition [44]. These studies also indicate that urban agglomerations do not show a single evolutionary stage of urban development, with a coexistence of different developmental waves, less regulated by fertility trends and more strongly dependent on international migration and increasing residential mobility at both younger and older ages [45].

This interpretative framework contributes to link economic theory with historical approaches grounded on a comparative understanding of the role of past cities' structure, being inherently influenced by land-use policies stimulating or containing settlement expansion, and (more or less strict) regulation of immigration [46]. According to Fox [47], "urbanization is better understood as a global historical process driven by population dynamics associated with technological and institutional innovations that have substantially improved disease control and food security in urban settlements across the globe. These innovations first emerged in Europe in the eighteenth and nineteenth centuries and were subsequently diffused through colonialism, trade, and international development assistance". 
Understanding the latent linkage between urbanization and population dynamics at various spatial scales revealed crucial when investigating demographic changes influenced by a mix of institutional, political, economic, and cultural factors [13,48-50], and is particularly useful for policy purposes. Being grounded on a wide-ranging comparison among cities, understanding urbanization processes relies, to a large extent, on the availability of accurate and consistent information on the spatial distribution, size and growth of metropolitan areas worldwide [51]. At the same time, (local and regional) developmental strategies increasingly oriented toward sustainability should more effectively govern the apparent and latent mechanisms of urban expansion, promoting a spatially balanced growth and an environmentally sustainable enlargement of metropolitan regions. However, despite a rising interest in the role of long-range urbanization on demographic processes around the world, a comparative knowledge of long-term population trends in metropolitan areas is still partial and fragmented [34,37,52]. Owing to the intrinsic conditions (e.g., social, cultural, political) of each urban context, contemporary cities gave increasing evidence of new, multifaceted relationships between demographic dynamics and the underlying socioeconomic context $[43,53,54]$. For instance, while the highest rates of population growth in advanced economies were observed in the 1960s and the 1970s, more heterogeneous demographic patterns characterize emerging countries and reflect inherent transformations in socio-spatial structures and a persistent polarization in metropolitan and non-metropolitan areas [2].

A comprehensive understanding of developmental patterns in metropolitan regions worldwide may therefore benefit from a long-term, comparative analysis of spatially explicit patterns of population expansion. Results of this analysis allow identification of sequential phases of urban growth and decline, informing policy design and implementation of a strategy for sustainable metropolitan development. Analysis of urban cycles was traditionally based on a scheme interpreting urban development as a sequence of separate stages of growth, starting from compact and dense urbanization and finishing with a more complex and latent re-urbanization phase (Figure 1). In this regard, investigating the relationship between city size (measures as total population) and city-level rates of population growth-considered as a basic demographic indicator of regime shift—can provide the necessary background to achieve a comprehensive overview of recent urban trends [55]. Deviations from the abovementioned scheme may indicate more complex development patterns that require specific investigation. Although based on a simplified analysis of the long-term evolution of metropolitan system, the city life cycle was (and is still) considered a background interpretation of apparent (and latent) mechanisms of urban growth $[34,46]$ that can be integrated with refined approaches to metropolitan complexity $[1,30,41]$. This framework seems to be particularly appropriate when investigating the present and future evolution of metropolitan systems experiencing late re-urbanization, which is considered a particularly hard task because of the inherent volatility of population dynamics in contemporary cities [38,43,51].

Based on these premises, the purpose of our work is to investigate spatio-temporal shifts in the relationship between city size and population growth over a sufficiently long time period (1950-2030) in 1857 world cities with at least 300,000 inhabitants (or more) in 2014. The analysis allows identification of spatial similarities in metropolitan expansion, so as to infer relevant characteristics and timing of urban cycles by continents, macro-regions or homogeneous economic areas. The sample considered in this work includes cities from 154 countries and is representative of global urban conditions and population trends [45]. Based on largely differentiated demographic dynamics [25,32,56], the present work brings insight to the debate over the present and future development of urban agglomerations worldwide. 


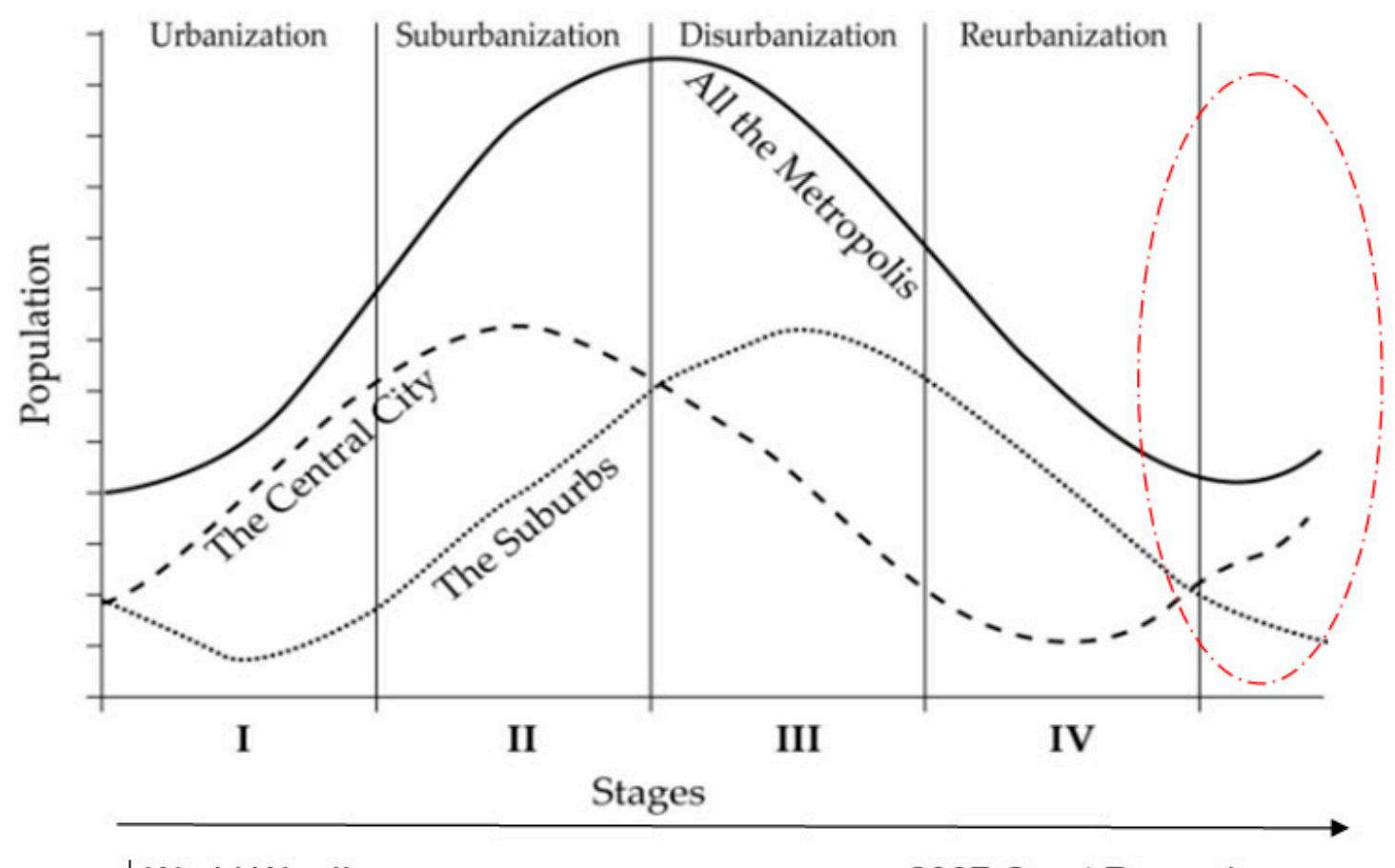

| World War ||

2007 Great Recession

Figure 1. A general scheme of the 'City Life Cycle' covering the time interval between World War II and nowadays: the ellipse indicates the most recent urban dynamics; the arrow indicates time.

\section{Methodology}

\subsection{Elementary Data and Variables}

This study investigates the relationship between population growth rate and city size at the metropolitan scale between 1950 and 2030 in 154 world countries. Total population living in 1857 agglomerations with more 300,000 inhabitants at 2014 was derived from recent statistics published by the Department of Economic and Social Affairs, Population Division of the United Nations. Urban population was predicted for the period 2015-2030 following the methodology elaborated by World Urbanization Prospects [45]. The Population Division of the Department of Economic and Social Affairs of the United Nations has been issuing for several decades revised estimates and projections of the urban and rural populations of all countries in the world and of their major urban agglomerations. More specifically, we considered the main findings of the 2018 Revision of World Urbanization Prospects, which are consistent with the size of the total population of each country as estimated or projected in the 2017 Revision of World Population Prospects (United Nations). The World Urbanization Prospects are used widely throughout the United Nations and by many international organizations, research centres, academic researchers, and the media.

Including a short-term, official population forecast (2015-2030) in the analysis allows formulation of future demographic scenarios, evidencing their contribution to a refined investigation of new global urban cycles. World Urbanization Prospects use a robust extrapolation method to project urban population by country and agglomeration, assuming variable urban-rural growth differences over the projection period. The method is based on the urban-rural ratio, which was calculated for the last two empirical data points available - which are typically based on results from two censuses. An average annual rate of change in the urban-rural ratio was then calculated, being equivalent to the difference between the rate of change of urban population and the rate of change of the rural population. This rate of change was extrapolated assuming that the proportion urban follows a logistic path. In a subsequent step, empirical urban-rural growth differences were estimated for two groups of countries with different population size (more or less than 2 million inhabitants in 2018) using regression models. 
This "hypothetical urban-rural growth difference" for each level of an initial observed percentage urban was then applied to the most recent urban-rural growth difference of a given country (obtained in the first step) and adapted to the hypothetical urban-rural growth difference of all countries of the world (obtained in the second step) over a period of 25 years. Based on observed and estimated data, the annual (per cent) rate of population growth for each agglomeration was calculated for 8 ten-year intervals (1950-1960, 1960-1970, . , 2020-2030) and absolute population size was calculated at the beginning of each time interval $(1950,1960, \ldots, 2020)$.

\subsection{Statistical Analysis}

To investigate the spatial distribution of urban population over time, descriptive statistics (average and coefficient of variation) were computed on the spatial series of population growth rates by metropolitan agglomeration and time interval. Based on geographical, political and cultural criteria, agglomerations were aggregated in 9 macro-regions (see Appendix A) including cities in (i) Africa, (ii) China, (iii) Russia and other countries historically under the Soviet influence, (iv) India, (v) other Asian countries, (vi) Middle East countries, (vii) Europe, (viii) North America and (ix) Latin America (see Appendix A). Macro-regions were designed to make a clear distinction between the old and the new world, considering relevant characteristics and timing of urban cycles, with the final objective to partition the sample of cities in spatially homogeneous groups with comparable size. This partition is also coherent with the indications provided by World Urbanization Prospects aimed at distinguishing (over a long-term period, 1950-2030) advanced economic systems (Europe, North America, Russia) from emerging (fast growing) countries (China, India, Latin America, Asia, Middle East) and developing countries (Africa). The number of cities in each macro-region ranges between 434 agglomerations in China and 108 in Russia. A sample of more than 100 agglomerations was considered enough stable to provide statistical results generalizable to the entire region [2,5]; this assumption provides an additional justification to the spatial partition in 9 world macro-regions adopted in this study.

The relationship between city size (total metropolitan population at a given time point, $t_{0}$, log-transformed) and per cent annual population growth rate at a given time interval $\left(t_{1}-t_{0}\right)$ was investigated using parametric and non-parametric pairwise correlation analysis [57]. Pearson moment-product and Spearman rank coefficients were calculated separately for each time point and macro-region, testing for significance at $p<0.001$ after Bonferroni's correction for multiple comparisons [58]. The joint use of parametric and non-parametric correlation coefficients allows for the identification of both linear and non-linear relationships, making the inferential analysis intrinsically more powerful, especially when using variables with (more or less intense) deviation from normality [59].

A factor analysis (FA) was run separately on Pearson and Spearman correlation matrices (by time interval and macro-region) with the aim to discriminate population trends reflecting distinctive spatial regimes in demographic dynamics and the relationship with city size across macro-regions over the entire study period. Eigenvalues $>1$ were extracted and further analysed, evidencing the structure of loadings (time) and scores (space) with the aim to identify regional specificities in the above-mentioned relationship. A classification tree built-up through hierarchical clustering (Euclidean distance with Ward's agglomeration rule) was finally run on the same data matrix used as input for FA (see above) with the aim to assess timing of population growth (or shrinkage) and the intrinsic role of city size. Hierarchical clustering identifies patterns of similarity or divergence in large datasets referring to input variables, input cases or both [60]. Hierarchical clustering was considered appropriate to identify time intervals with homogeneous population trends [49]. The integration of different exploratory techniques allows for a refined analysis of large datasets distinguishing among demographic regimes and verifying distinctive models of urban growth at regional scale [21]. 


\section{Results}

\subsection{Population Trends in Metropolitan Areas Worldwide, 1950-2030}

A comparative analysis of per cent annual population growth rates (Table 1) covered a total of 1857 metropolitan areas (aggregated in 9 macro-regions) on a 10-year time step between 1950 and 2030. On average, metropolitan population worldwide increased by $6.5 \%$ per year in the 1950 s with rates of growth above $5 \%$ per year in the subsequent four decades, up to the late 1990s. Since 2000, population growth decelerated in every macro-region up to 3.1\% (2000-2010) and is estimated at $2.7 \%$ for 2010-2020 and 1.9\% for 2020-2030. Spatial variability in population growth rates at metropolitan scale was relatively low in the first three decades of investigation (1950-1980), increased markedly in the following three decades (1980-2010), and is estimated to decrease even more rapidly in the present and coming decades. This trend was coherently observed at the global level and in every macro-region, with the only exception of Russia and, in part, India and the Middle East.

Table 1. Average metropolitan population growth rate (and the related coefficient of variation) by time interval and world macro-region, 1950-2030.

\begin{tabular}{|c|c|c|c|c|c|c|c|c|}
\hline Region & $1950-1960$ & 1960-1970 & 1970-1980 & 1980-1990 & 1990-2000 & 2000-2010 & 2010-2020 & 2020-2030 \\
\hline \multicolumn{9}{|l|}{ Average } \\
\hline Africa & 8.87 & 8.57 & 7.35 & 6.22 & 5.04 & 4.47 & 4.41 & 4.04 \\
\hline China & 8.14 & 7.59 & 7.53 & 8.28 & 13.36 & 4.33 & 3.67 & 2.20 \\
\hline Europe & 1.93 & 1.73 & 1.04 & 0.67 & 0.30 & 0.52 & 0.64 & 0.42 \\
\hline India & 5.21 & 4.77 & 4.92 & 4.57 & 3.71 & 3.23 & 3.10 & 2.63 \\
\hline North America & 4.77 & 3.71 & 2.78 & 3.07 & 3.25 & 2.09 & 2.00 & 1.13 \\
\hline Russia & 4.79 & 4.77 & 3.70 & 1.47 & 0.22 & 0.68 & 1.06 & 0.49 \\
\hline Grand Mean & 6.54 & 6.22 & 5.75 & 5.44 & 5.76 & 3.13 & 2.72 & 1.91 \\
\hline \multicolumn{9}{|c|}{ Coefficient of variation } \\
\hline Africa & 0.76 & 0.77 & 0.81 & 1.25 & 0.85 & 0.65 & 0.61 & 0.37 \\
\hline Asia & 0.75 & 0.68 & 0.74 & 0.85 & 1.04 & 1.09 & 0.99 & 0.75 \\
\hline Latin America & 0.70 & 0.88 & 0.84 & 0.97 & 0.52 & 0.53 & 0.49 & 0.38 \\
\hline Middle East & 0.74 & 0.73 & 0.82 & 0.83 & 0.76 & 1.23 & 0.82 & 0.54 \\
\hline North America & 0.81 & 1.07 & 1.07 & 1.88 & 1.24 & 0.98 & 0.99 & 0.47 \\
\hline Russia & 0.85 & 0.77 & 1.81 & 0.91 & 4.98 & 2.20 & 1.58 & 2.10 \\
\hline Grand CV & 0.85 & 0.87 & 0.93 & 1.19 & 1.42 & 1.01 & 0.86 & 0.71 \\
\hline
\end{tabular}

Except for Chinese agglomerations during 1990-2000, African cities maintained the highest rate of growth during the entire study period, spanning from 9\% (1950-1960) to 4\% (2020-2030). China, Middle East, and Latin American agglomerations experienced an accelerated growth up to the late 2000s but are estimated to expand slowly in the coming decade. Indian and the remaining Asian cities (except China, Russia and India) experienced a relatively high and persistent rate of population growth. North American cities showed accelerated dynamics in the first decades, decelerating slowly since the early 2000s. While displaying accelerated dynamics in the first three decades of investigation, Russian cities experienced a moderate population increase since the early 1980. Finally, European cities displayed the lowest rate of growth over the entire study period. These evidence suggest that Europe, likely the most mature and consolidated metropolitan system in the world, was anticipating population trends that are (and will be) observed in the other regions, with a further delay between advanced economies with accelerated dynamics (North America, Russia), emerging economies with mixed dynamics (Asia, China, India, Latin America) and developing countries with late growth (Africa and, in part, Middle East). 


\subsection{Correlation Analysis}

The results of the correlation analysis between city size and population growth rate were reported in Table 2. The values of Pearson's parametric and Spearman's non-parametric correlation coefficients of Spearman were convergent for all macro-regions and time intervals. Slight discrepancies were observed only for the most recent decades and are associated with low rates of urban population growth. In the first two decades of study (1950-1960 and 1960-1970), correlation coefficients were significantly negative in all macro-regions.

Table 2. Correlation analysis between city size and population growth rate by time interval and macro-region (bold indicates significant coefficients at $p<0.001$ after Bonferroni's correction for multiple comparisons).

\begin{tabular}{|c|c|c|c|c|c|c|c|c|}
\hline Region & 1950-1960 & 1960-1970 & 1970-1980 & 1980-1990 & 1990-2000 & 2000-2010 & 2010-2020 & 2020-2030 \\
\hline \multicolumn{9}{|c|}{ Pearson moment product parametric correlation coefficients } \\
\hline Africa & -0.430 & -0.396 & -0.369 & -0.391 & -0.430 & -0.380 & -0.223 & -0.032 \\
\hline Asia & -0.317 & -0.245 & -0.295 & -0.558 & -0.502 & -0.373 & -0.142 & -0.036 \\
\hline China & -0.687 & -0.792 & -0.739 & -0.371 & -0.518 & -0.254 & -0.207 & -0.056 \\
\hline Europe & -0.346 & -0.391 & -0.345 & -0.327 & -0.138 & -0.009 & 0.029 & 0.102 \\
\hline Inia & -0.436 & -0.259 & -0.151 & -0.253 & -0.238 & -0.238 & -0.07 & 0.086 \\
\hline Latin America & -0.480 & -0.485 & -0.407 & -0.401 & -0.266 & -0.231 & -0.135 & 0.001 \\
\hline Middle East & -0.646 & -0.600 & -0.544 & -0.531 & -0.598 & -0.400 & -0.379 & -0.096 \\
\hline North America & -0.293 & -0.400 & -0.636 & -0.546 & -0.489 & -0.414 & -0.288 & -0.140 \\
\hline Russia & -0.714 & -0.647 & -0.432 & -0.409 & -0.237 & -0.202 & -0.067 & 0.145 \\
\hline \multicolumn{9}{|c|}{ Spearman non-parametric correlation coefficients } \\
\hline Africa & -0.467 & -0.375 & -0.396 & -0.387 & -0.460 & -0.418 & -0.257 & -0.008 \\
\hline Asia & -0.257 & -0.217 & -0.251 & -0.597 & -0.605 & -0.404 & -0.124 & 0.114 \\
\hline China & -0.726 & -0.805 & -0.787 & -0.675 & -0.622 & -0.324 & -0.210 & 0.018 \\
\hline Europe & -0.361 & -0.409 & -0.336 & -0.339 & -0.159 & -0.044 & 0.006 & 0.101 \\
\hline Inia & -0.250 & -0.202 & -0.161 & -0.253 & -0.208 & -0.216 & -0.091 & 0.101 \\
\hline Latin America & -0.426 & -0.441 & -0.396 & -0.410 & -0.183 & -0.188 & -0.090 & 0.032 \\
\hline Middle East & -0.580 & -0.553 & -0.624 & -0.518 & -0.499 & -0.321 & -0.368 & -0.113 \\
\hline North America & -0.348 & -0.394 & -0.592 & -0.400 & -0.484 & -0.402 & -0.287 & -0.092 \\
\hline Russia & -0.609 & -0.642 & -0.649 & -0.339 & -0.340 & -0.225 & -0.082 & 0.127 \\
\hline
\end{tabular}

The highest correlation coefficients in these periods were observed for Chinese cities, the Middle East and Russia. This means that population growth rate in these agglomerations was inversely proportional to city size. Even in the following two decades, the correlation between urban size and population growth was negative and highly significant in all macro-regions, except for India (1970-1980). The highest correlation coefficients were observed in the 1970s in Chinese, North American, Middle East, and Russian cities (Pearson's coefficients higher than Spearman's coefficients). In the 1980s, the highest correlation coefficients were observed in the Asian macro-region, in the Middle East, in North America (Spearman's coefficients higher than Pearson's coefficients) and in China (Pearson's coefficients higher than Spearman's coefficients).

In the 1990s, correlation coefficients began to decline, although they remained statistically significant in almost all macro-regions (except for Europe and Russia). The highest values were observed in China, in other Asian countries and in the Middle East. North America, Latin America and Africa had negative and significant correlation coefficients, but lower than those observed in the macro-regions mentioned above. In the following decade (2000-2010), Europe and Russia showed non-significant correlation coefficients. On the contrary, the highest negative coefficients were observed in African and Asian macro-regions, as well as in the Middle East. The correlation between city size and population growth was particularly high and negative in North America.

In the most recent decade, the correlation coefficients between size and population growth decreased in most of the macro-regions. Based on population projections for 2020, this correlation is significantly negative in only three macro-regions (Africa, Middle East and North America). A weaker evidence of negative correlation between the two dimensions is observed in China. In the last decade 
of study, it is estimated that the relationship between city size and population growth will be not significant in all macro-regions.

\subsection{Multivariate Analysis}

Factor Analysis (FA) run separately on the two correlation matrices (Pearson and Spearman) identifies two main axes explaining together $89.7 \%$ of the overall variance in the case of the Pearson's matrix and $92.7 \%$ in the case of the Spearman's matrix and illustrating highly differentiated, non-linear urban trajectories (Figures 2 and 3). These pathways are basically due to distinctive trends: the former observed between the 1950s and the 1990s (high loadings declining over time along component 2), the latter observed in the subsequent decades (higher loadings growing with time along the component 1 ).

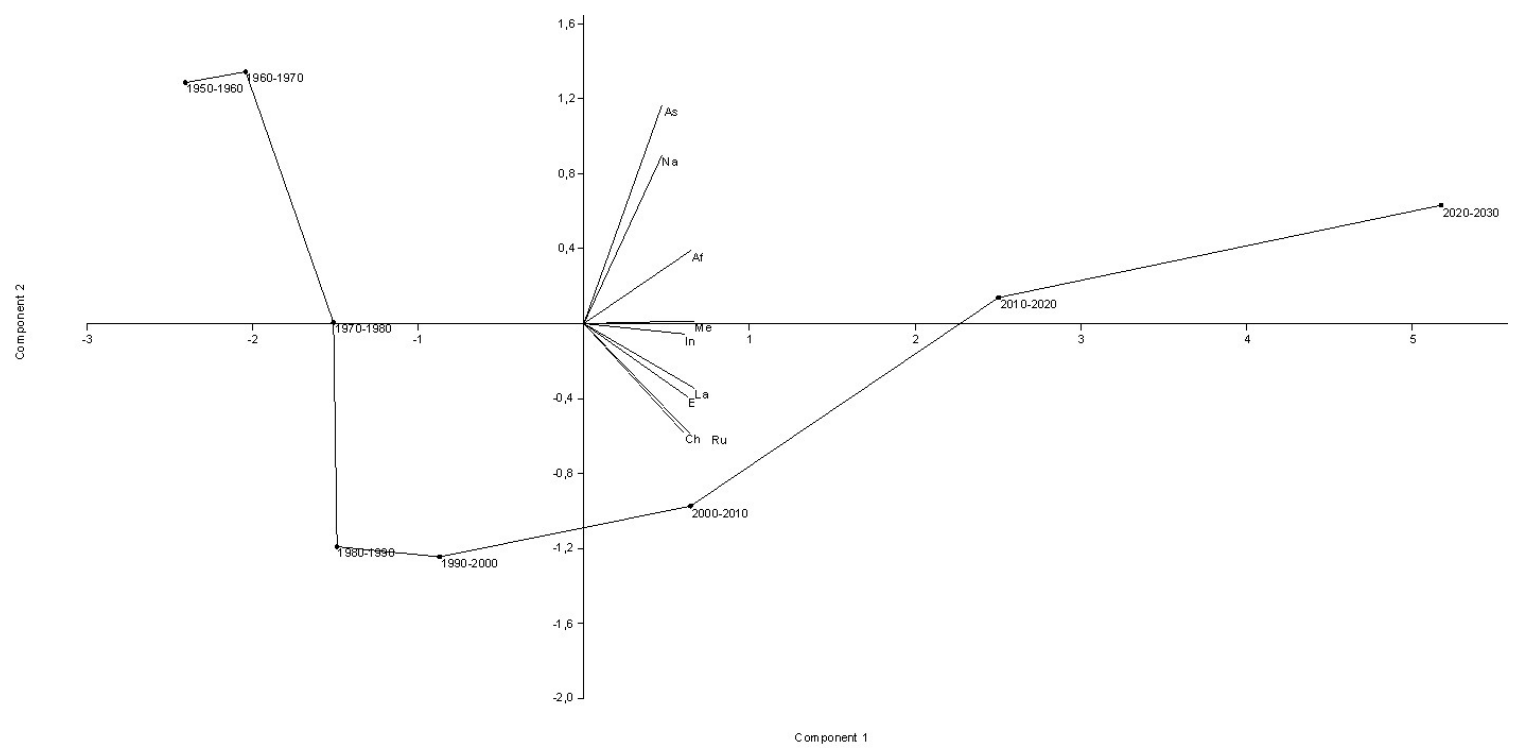

Figure 2. Results of a Factor Analysis run on the correlation matrix of Pearson coefficient (see Table 2).

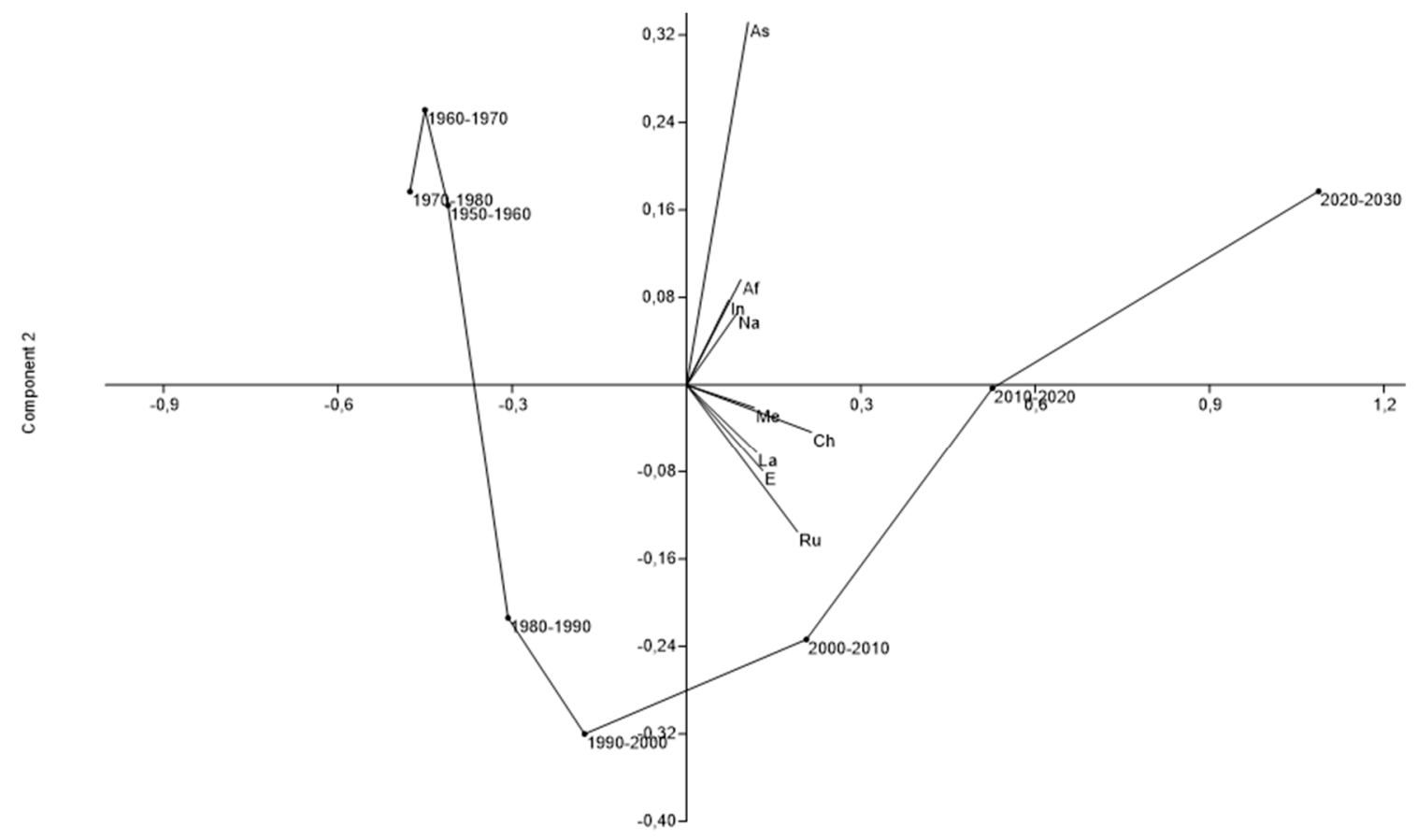

Component 1

Figure 3. Results of a Factor Analysis run on the correlation matrix of Spearman coefficient (see Table 2). 
Results of the FA differentiate world macro-regions based on the first two components. China, Russia, Europe and Latin America are the regions that received the highest and negative loadings along component 2, experiencing the highest growth rates and the most significant (negative) correlation with city size in the first phase. Urban agglomerations in Africa, North America, the rest of Asia and, in part, Middle East and India, were more closely linked to population dynamics observed since the 1990s. In these regions, high rates of growth have been observed even in the most recent decades, being still related negatively to city size.

Results of a hierarchical clustering allow identification of time intervals with homogeneous population trends and negative correlation with city size, possibly contributing to define urban cycles characterized by distinctive demographic regimes (Figure 3). Notably, clusters on Pearson and Spearman correlation matrices provided similar results. Small differences between the two dendrograms contribute to better profile the characteristics of urban cycles. Ward's clustering on Pearson correlation matrix provided a simplified discrimination between earlier decades (between the 1950s and the 1990s, with two particularly homogeneous decades: 1950s and 1960s) and a more recent period encompassing the last two decades (2000s and 2010s) and the coming one (2020-2030). Ward's clustering on Spearman correlation matrix separated three homogeneous decades (1950s, 1960s and 1970s) from a longer time period (between the early 1980s and the late 2010s) displaying a marked heterogeneity in respect with earlier decades. The coming years (2020-2030) are represented as an outlier period based on the different correlation regime between city size and population growth.

\section{Discussion}

Long-term urbanization patterns worldwide underlie the inherent influence of multiple factors of growth and change, with a prominent role of demographic dynamics [30,61-63]. However, metropolitan growth was far from being a homogeneous process over space and time, since different types of population dynamics and relationship with city size influenced long-term urban cycles, shaping the overall spatial structure of metropolitan regions and their socioeconomic role in the global arena $[10,20,23,64,65]$. Emerging approaches in urban studies attempt to combine theoretical perceptions behind scale and agglomeration effects with a definite focus on demographic effects within cities which may inspire a more comprehensive analysis of metropolitan systems, going beyond the linear interpretation imposed by economic laws, both theoretically-oriented and empirically grounded $[11,14,34,46]$. While being based on exploratory thinking, correlation analysis and multivariate statistics allow a detailed analysis of global urban cycles, contributing to clarify the interplay between long-term demographic dynamics and short-term urban transitions $[5,25,26]$.

Analysis of sequential phases of urban expansion, characterized by distinctive rates of urban expansion and varying intensity of the relationship between city size and rates of population growth, provides a useful contribution to analysis of different metropolization patterns and processes. In these regards, the present study overcomes analysis' gaps - mainly referring to a spatially explicit, long-term investigation of global urban cycles vis à vis population dynamics, under the framework of the second demographic transition, reflecting fertility decline, ageing, and a more volatile impact of migration on regional and urban dynamics $[6,8,19]$.

The results of our study indicate that metropolitan expansion was associated with largely variable rates of population growth, highly positive before 2000 and reducing progressively over more recent years. Despite important differences at the regional scale, population growth in urban agglomerations reflects contrasting demographic regimes with a break point in the late 1980s or early 1990s - depending on the world macro-region. More specifically, the 1990s were a transitional period from a spatially homogeneous demographic regime based on high rates of population growth strictly dependent on city size, to a different regime grounded on low rates of population growth varying over space irrespective of city size [24]. The transitional phase was characterized by spatially heterogeneous dynamics of growth, either between and within macro-regions, and a decline in the strength of the correlation between city size (population) and demographic growth [29]. In this period, the coefficient 
of variation in population growth rates was particularly high in every macro-region (with a particularly high value observed in Europe, North America and Russia). At the same time, the correlation between city size and demographic growth was more evident when urban population grew rapidly, evidencing a latent process of convergence between smaller and larger cities. More specifically, global demographic change-with pronounced falls in fertility and mortality in emerging economies-has led to a progressive convergence of demographic patterns around the world, including vital rates and population size [15].

Increasingly mixed patterns of demographic growth were observed for urban agglomerations in both advanced and emerging countries, evidencing common patterns beyond the traditional economic polarization in advanced and emerging countries or socio-political and cultural divides (e.g. global north vs south, or 'western' vs 'eastern' urban systems). These results also justify a refined investigation of the long-term contribution of short-range and long-range migration to metropolitan growth worldwide. In this regard, sequential cycles typically representing urbanization, suburbanization, counter-urbanization and re-urbanization were (and are) progressively replaced by more complex and unpredictable waves of urban expansion reflecting specific developmental paths at both regional and local scale - often decoupled from demographic trajectories typical of leading countries $[22,49,58]$. The spatial dimension of urban growth was revealed to be particularly important since 2000, evidencing the role of individual city dynamics beyond traditional gradients. These processes outline a more complex population geography for the most recent decades $[10,16,51,65]$.

Urban population trends essentially show two ways of metropolitan expansion, the former linked to particularly high population growth rates (supported by positive natural balance and immigration), even higher in small and intermediate cities than in large cities, the latter linked with medium-low growth rates irrespective of city size. The first trend is linked to country-specific outcomes of the second demographic transition, and in some ways reinforced it, supporting a classical model of accelerated urbanization based on demographic convergence of smaller agglomerations towards larger ones, and the progressive saturation of urban growth in mega-city regions [4].

The second pathway includes the most recent demographic dynamics and clearly highlights a greater complexity and spatial heterogeneity of urban growth, linked to a generalized reduction of fertility and an increasing role of migration balance (which gives a more volatile contribution to urban growth than natural balance [42]). As population growth rates were supported almost exclusively by migration, the strength of the relationship between city size and population expansion declined rapidly. These results underline the increasing importance of individual development paths, where local factors weigh much more than regional demographic dynamics and latent trends toward more globalized socioeconomic contexts. Taken together, such findings indicate that urban growth is (and will increasingly be) a process driven by heterogeneous factors in both time and space. With this new growth regime, predictability of future urban expansion is greatly reduced, being less and less dependent on demographic dynamics linked to the natural balance, and increasingly associated with migration, in turn dependent on both economic drivers and geo-political constraints [17]. Increasing the unpredictability (and more place-specific mechanisms) of metropolitan growth may reduce the effectiveness of strategies for sustainable urban development, forcing policy design to be increasingly context-based, considering individual growth paths more carefully than regional, country and global trends.

At the regional scale, urban-demographic dynamics highlighted in our study fundamentally distinguish the old world (Eurasia) from the new world (Africa, America, the remaining part of Asia and Oceania), with some transitional regions in-between (India and the Middle East). This demographic polarization goes beyond the classic developmental model separating affluent countries from emerging economies and clarifies the importance of non-economic factors in individual urban development pathways - in a context of low fertility and more volatile contribution of migration to metropolitan growth [27]. While cities command an increasingly dominant role in the global economy as centres of production and consumption, empirical findings of this study and earlier research [47] contribute to 
demonstrate that alternative (e.g., historically, socially and demographically grounded) theories of urban growth may enrich the explanation for the stylized facts of urban population transition provided by traditional economic frameworks, highlighting the legacy of historical, cultural, institutional, and religious factors [39].

Recent population trends, and especially the decoupling of population growth from city size may be also associated to incipient phenomena of urban shrinkage. While the majority of metropolitan agglomerations experienced a continuous process of urban growth, some others have undergone (more or less) long periods of shrinkage over recent decades. Spatial demography is a fundamental factor contributing to shrinkage, being in turn related to specific local contexts [19]. Apart from Europe experiencing an intense shrinkage in the last two decades [43], demographic shrinkage was deepening in Japan, indicating local conditions characterized by a 'double-negative population disequilibrium', whereby both the migratory and natural contribution to population growth have turned negative [17]. In Russia, shrinkage was primarily associated with different urban functions, consolidating territorial disparities [65]. Demographic shrinkage was also observed in China, with shrinking cities rising by $71 \%$ from 164 in the 1990s to 281 in the 2000s [66]. In the United States, these results are even more complicated thanks to unanticipated shifts in metropolitan-nonmetropolitan population change and migration, with the latter being acknowledged as a key driver of regional diversity in population dynamics [67]. Taken together, such dynamics are reflected in the empirical results of the correlation analysis presented in our study.

These findings are also of particular interest for refining city-scale and regional-scale population projections that take account of the recent evolution of metropolitan systems, with urban growth shifting from a spatially homogeneous process governed by urban density and agglomeration factors toward more heterogeneous dynamics driven by regional scale factors and city-level processes, identifying the expanding role of individual trajectories of growth in metropolitan agglomerations [68-70]. According to a global scenario [54], the degree of convergence in urbanization across countries will differ substantially as a result of population dynamics that are typical of regions in different stages of urbanization and development levels, as clearly revealed in our analysis.

\section{Conclusions}

For the first time in history, the majority of the world population now lives in cities. Global urbanization will continue at high speed with the world's urban population is projected to increase by more than 3 billion people between 2010 and 2050. While cities maintain a key role in shaping worldwide population trends, different developmental paths emerge depending on the rate of urbanization, possibly indicating that future demographic dynamics will overlap only partly with those observed in the past, being less sequential and more unpredictable and heterogeneous over space. A refined comprehension of worldwide metropolitan cycles is gaining a decisive role in a globalized economic system where, together with increasing emphasis on sustainable development, the importance of the demographic dimension of urban growth has been strengthened.

Urban agglomerations with high rates of population expansion combined with cities growing moderately and even with towns experiencing demographic shrinkage, making analysis of population trends in metropolitan regions a particularly complex and challenging task. In this framework, the contribution of natural balance (births and deaths) to population growth in metropolitan regions has progressively declined, leaving urban growth driven largely by migration. Supra-national and country-specific developmental policies could be inadequate or inefficient in promoting a sustainable urban development in metropolitan regions of both advanced and emerging countries without considering the specificity of local contexts and intrinsic demographic dynamics.

Intensity of urban expansion and spatial heterogeneity among metropolitan agglomerations definitely express a trade-off between 'fast' (e.g., migration) and 'slow' (e.g., change in natural balance) demographic dynamics [8]. This trade-off can be more intensively investigated to support recently proposed theories of sequential city growth, making a relevant contribution to policy making, 
especially in countries where urban growth is still evident [66]. Innovative approaches for the large-scale modelling of global demographic processes are vital to the study of metropolitan growth, while being also linked to issues of socioeconomic development [29]. These questions need to be further investigated to dealt with future urbanization waves and demographic dynamics worldwide.

To cope with these deserving research questions, a consistent set of global urbanization projections that cover long time horizons and span a full range of uncertainty is increasingly required. Existing urbanization projections, including those from United Nations Population Division extensively used in our study, provide only a single scenario over the next few decades, a period during which urbanization is likely to be highly dynamic in many countries. A long-term, new global set of urbanization projections at country level should be developed that cover a plausible range of uncertainty [62].

To provide policymakers with useful scientific guidance in the upcoming urban era, researchers will finally need to refine their data sets to include spatial factors as well as city-scale vital rates and to make improvements to forecasting methods currently in use [31]. A comparative analysis of spatially detailed and updated population data is also required to assess newly emerging demographic patterns associated to complex socioeconomic processes acting at different spatial scales.

Author Contributions: Conceptualization, L.S. and R.H.-C.-Z.; methodology, L.S.; software, S.C.; validation, S.C., formal analysis, L.S.; investigation, R.H.-C.-Z.; resources, R.H.-C.-Z.; data curation, S.C.; writing—original draft preparation, L.S.; writing-review and editing, R.H.-C.-Z.; visualization, S.C.; supervision, S.C.; project administration, S.C.; funding acquisition, R.H.-C.-Z. All authors have read and agreed to the published version of the manuscript.

Funding: The APC was supported by a grant of the Romanian Ministery of Research and Innovation, project number 10PFE/16.10.2018, PERFORM-TECH-UPT - The increasing of the institutional performance of the Polytechnic University of Timisoara by strengthening the research, development and technological transfer capacity in the field of "Energy, Environment and Climate Change", within Program 1-Development of the national system of Research and Development, Subprogram 1.2-Institutional Performance - Institutional Development Projects - Excellence Funding Projects in RDI, PNCDI III".

Conflicts of Interest: The authors declare no conflict of interest. The funders had no role in the design of the study; in the collection, analyses, or interpretation of data; in the writing of the manuscript, or in the decision to publish the results.

\section{Appendix A}

Table A1. List of countries reporting the number of cities classified in each world region (part 1).

\begin{tabular}{|c|c|c|c|c|c|c|c|c|c|c|}
\hline Country & Africa & Asia & China & Europe & India & $\begin{array}{c}\text { Latin } \\
\text { America }\end{array}$ & $\begin{array}{c}\text { Middle } \\
\text { East }\end{array}$ & $\begin{array}{c}\text { North } \\
\text { America }\end{array}$ & Russia & Total \\
\hline Afghanistan & & & & & & & & & 4 & 4 \\
\hline Albania & & & & 1 & & & & & & 1 \\
\hline Algeria & 8 & & & & & & & & & 8 \\
\hline Angola & 9 & & & & & & & & & 9 \\
\hline Argentina & & & & & & 17 & & & & 17 \\
\hline Armenia & & & & & & & & & 1 & 1 \\
\hline Australia & & 11 & & & & & & & & 11 \\
\hline Austria & & & & 1 & & & & & & 1 \\
\hline Azerbaijan & & & & & & & & & 3 & 3 \\
\hline Bahrain & & & & & & & 1 & & & 1 \\
\hline Bangladesh & & 11 & & & & & & & & 11 \\
\hline Belarus & & & & 6 & & & & & & 6 \\
\hline Belgium & & & & 5 & & & & & & 5 \\
\hline Benin & 4 & & & & & & & & & 4 \\
\hline Bolivia & & & & & & 4 & & & & 4 \\
\hline Bosnia and Herzegovina & & & & 1 & & & & & & 1 \\
\hline Brazil & & & & & & 59 & & & & 59 \\
\hline Bulgaria & & & & 3 & & & & & & 3 \\
\hline Burkina Faso & 2 & & & & & & & & & 2 \\
\hline Burundi & 1 & & & & & & & & & 1 \\
\hline Cambodia & & 1 & & & & & & & & 1 \\
\hline
\end{tabular}


Table A1. Cont.

\begin{tabular}{|c|c|c|c|c|c|c|c|c|c|c|}
\hline Country & Africa & Asia & China & Europe & India & $\begin{array}{c}\text { Latin } \\
\text { America }\end{array}$ & $\begin{array}{l}\text { Middle } \\
\text { East }\end{array}$ & $\begin{array}{c}\text { North } \\
\text { America }\end{array}$ & Russia & Total \\
\hline Cameroon & 7 & & & & & & & & & 7 \\
\hline Canada & & & & & & & & 17 & & 17 \\
\hline Central African Republic & 1 & & & & & & & & & 1 \\
\hline Chad & 1 & & & & & & & & & 1 \\
\hline Chile & & & & & & 6 & & & & 6 \\
\hline China & & & 424 & & & & & & & 424 \\
\hline China, Hong Kong SAR & & & 1 & & & & & & & 1 \\
\hline China, Macao SAR & & & 1 & & & & & & & 1 \\
\hline China, Taiwan P. China & & & 8 & & & & & & & 8 \\
\hline Colombia & & & & & & 18 & & & & 18 \\
\hline Congo & 2 & & & & & & & & & 2 \\
\hline Costa Rica & & & & & & 3 & & & & 3 \\
\hline Côte d'Ivoire & 2 & & & & & & & & & 2 \\
\hline Croatia & & & & 1 & & & & & & 1 \\
\hline Cuba & & & & & & 3 & & & & 3 \\
\hline Czechia & & & & 2 & & & & & & 2 \\
\hline Dem. Republic Korea & & 5 & & & & & & & & 5 \\
\hline Dem. Republic Congo & 16 & & & & & & & & & 16 \\
\hline Denmark & & & & 1 & & & & & & 1 \\
\hline Djibouti & & 1 & & & & & & & & 1 \\
\hline Dominican Republic & & & & & & 2 & & & & 2 \\
\hline Ecuador & & & & & & 4 & & & & 4 \\
\hline Egypt & 13 & & & & & & & & & 13 \\
\hline El Salvador & & & & & & 1 & & & & 1 \\
\hline Equatorial Guinea & 1 & & & & & & & & & 1 \\
\hline Eritrea & 1 & & & & & & & & & 1 \\
\hline Estonia & & & & 1 & & & & & & 1 \\
\hline Ethiopia & 5 & & & & & & & & & 5 \\
\hline Finland & & & & 2 & & & & & & 2 \\
\hline France & & & & 20 & & & & & & 20 \\
\hline Gabon & 1 & & & & & & & & & 1 \\
\hline Gambia & 1 & & & & & & & & & 1 \\
\hline
\end{tabular}

Table A2. List of countries reporting the number of cities classified in each world region (part 2).

\begin{tabular}{|c|c|c|c|c|c|c|c|c|c|c|}
\hline Country & Africa & Asia & China & Europe & India & $\begin{array}{c}\text { Latin } \\
\text { America }\end{array}$ & $\begin{array}{c}\text { Middle } \\
\text { East }\end{array}$ & $\begin{array}{c}\text { North } \\
\text { America }\end{array}$ & Russia & Total \\
\hline Georgia & & & & & & & & & 1 & 1 \\
\hline Germany & & & & 22 & & & & & & 22 \\
\hline Ghana & 4 & & & & & & & & & 4 \\
\hline Greece & & & & 2 & & & & & & 2 \\
\hline Guatemala & & & & & & 1 & & & & 1 \\
\hline Guinea & 1 & & & & & & & & & 1 \\
\hline Guinea-Bissau & 1 & & & & & & & & & 1 \\
\hline Haiti & & & & & & 1 & & & & 1 \\
\hline Honduras & & & & & & 2 & & & & 2 \\
\hline Hungary & & & & 1 & & & & & & 1 \\
\hline India & & & & & 181 & & & & & 181 \\
\hline Indonesia & & 33 & & & & & & & & 33 \\
\hline Iran (Islamic Republic of) & & & & & & & 28 & & & 28 \\
\hline Iraq & & & & & & & 17 & & & 17 \\
\hline Ireland & & & & 1 & & & & & & 1 \\
\hline Israel & & & & & & & 4 & & & 4 \\
\hline Italy & & & & 32 & & & & & & 32 \\
\hline Jamaica & & & & & & 1 & & & & 1 \\
\hline Japan & & 33 & & & & & & & & 33 \\
\hline Jordan & & & & & & & 6 & & & 6 \\
\hline Kazakhstan & & & & & & & & & 9 & 9 \\
\hline Kenya & 6 & & & & & & & & & 6 \\
\hline Kuwait & & & & & & & 1 & & & 1 \\
\hline Kyrgyzstan & & & & & & & & & 1 & 1 \\
\hline Lao Dem. Republic & & 1 & & & & & & & & 1 \\
\hline Latvia & & & & 1 & & & & & & 1 \\
\hline Lebanon & & & & & & & 1 & & & 1 \\
\hline
\end{tabular}


Table A2. Cont.

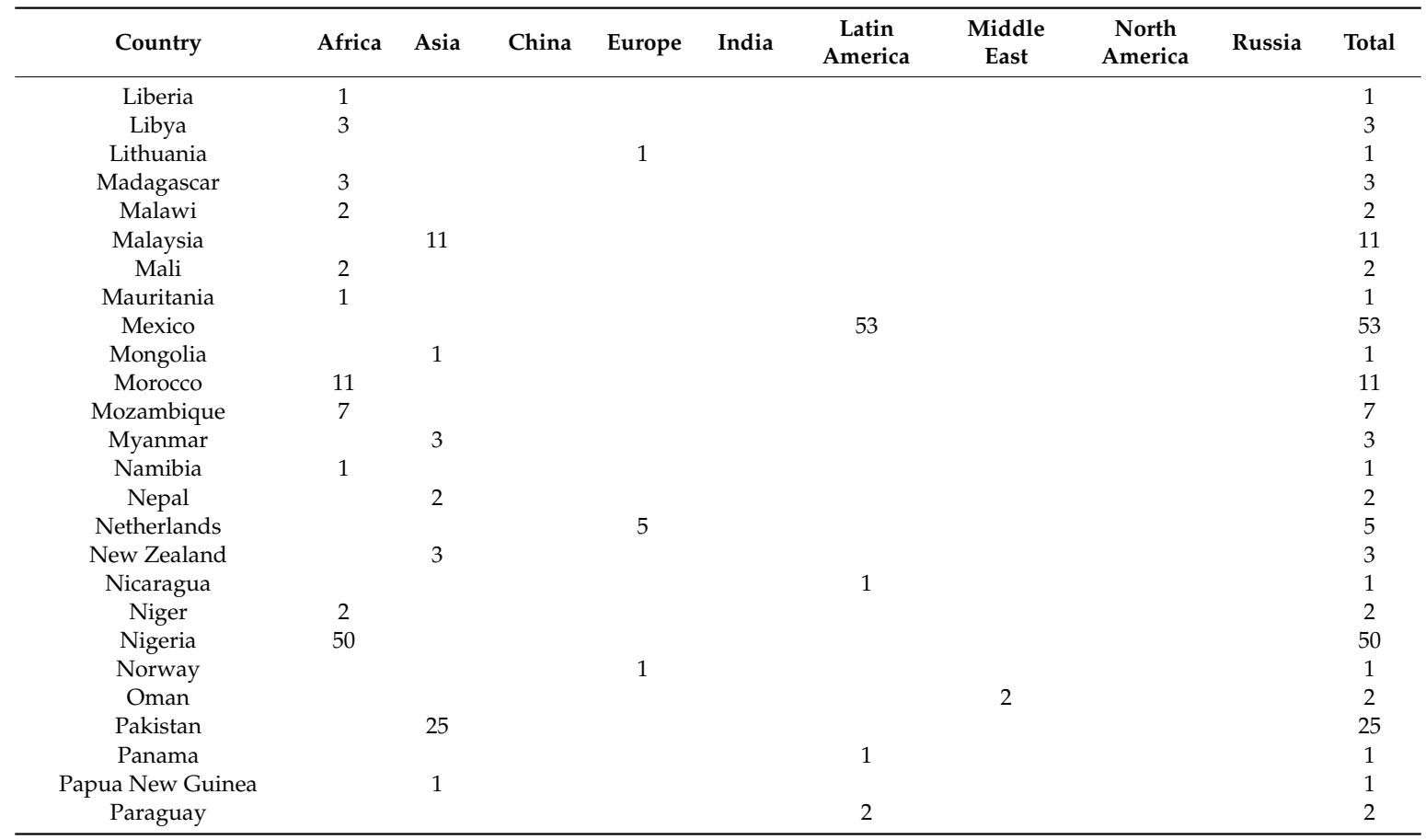

Table A3. List of countries reporting the number of cities classified in each world region (part 3).

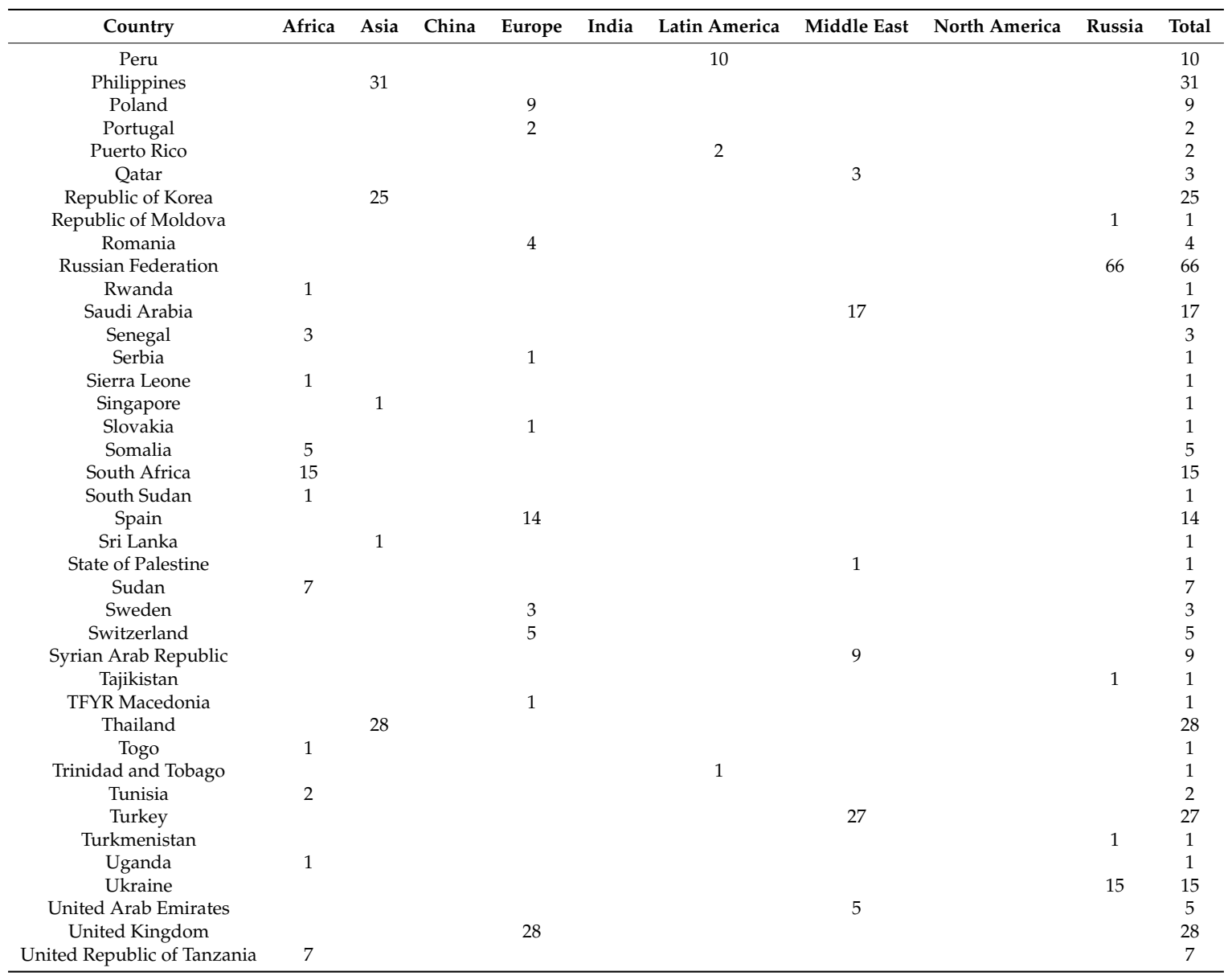


Table A3. Cont.

\begin{tabular}{|c|c|c|c|c|c|c|c|c|c|c|}
\hline Country & Africa & Asia & China & Europe & India & Latin America & Middle East & North America & Russia & Total \\
\hline United States of America & & & & & & & & 142 & & 142 \\
\hline Uruguay & & & & & & 1 & & & & 1 \\
\hline Uzbekistan & & & & & & & & & 5 & 5 \\
\hline Venezuela & & & & & & 16 & & & & 16 \\
\hline Viet Nam & & 11 & & & & & & & & 11 \\
\hline Yemen & & & & & & & 7 & & & 7 \\
\hline Zambia & 3 & & & & & & & & & 3 \\
\hline Zimbabwe & 3 & & & & & & & & & 3 \\
\hline Total & 220 & 239 & 434 & 178 & 181 & 209 & 129 & 159 & 108 & 1857 \\
\hline
\end{tabular}

\section{References}

1. Bettencourt, L.M.; Lobo, J.; Helbing, D.; Kühnert, C.; West, G.B. Growth, innovation, scaling, and the pace of life in cities. Proc. Natl. Acad. Sci. USA 2007, 104, 7301-7306. [CrossRef] [PubMed]

2. Angel, S.; Parent, J.; Civco, D.L.; Blei, A.; Potere, D. The dimensions of global urban expansion: Estimates and projections for all countries, 2000-2050. Prog. Plan. 2011, 75, 53-107. [CrossRef]

3. Alkema, L.; Jones, G.W.; Lai, C.U. Levels of urbanization in the world's countries: Testing consistency of estimates based on national definitions. J. Popul. Res. 2013, 30, 291-304. [CrossRef]

4. Buhaug, H.; Urdal, H. An urbanization bomb? Population growth and social disorder in cities. Glob. Environ. Chang. 2013, 23, 1-10. [CrossRef]

5. Chen, M.; Zhang, H.; Liu, W.; Zhang, W. The global pattern of urbanization and economic growth: Evidence from the last three decades. PLoS ONE 2014, 9, e103799. [CrossRef]

6. Wilson, C. On the scale of global demographic convergence 1950-2000. Popul. Dev. Rev. 2001, 27, $155-171$. [CrossRef]

7. Tabutin, D.; Schoumaker, B.; Rabenoro, M. The Demography of Sub-Saharan Africa from the 1950s to the 2000s. Population 2004, 59, 455-555. [CrossRef]

8. Véron, J.; Horko, K.; Kneipp, R.; Rogers, G. The demography of South Asia from the 1950s to the 2000s. Population 2008, 63, 9-89. [CrossRef]

9. Zitti, M.; Ferrara, C.; Perini, L.; Carlucci, M.; Salvati, L. Long-term Urban Growth and Land-use Efficiency in Southern Europe: Implications for Sustainable Land Management. Sustainability 2015, 7, 3359-3385. [CrossRef]

10. Tabutin, D.; Schoumaker, B.; Rogers, G.; Mandelbaum, J.; Dutreuilh, C. The Demography of the Arab World and the Middle East from the 1950s to the 2000s. Population 2005, 60, 505-615. [CrossRef]

11. Cohen, B. Urbanization in developing countries: Current trends, future projections, and key challenges for sustainability. Technol. Soc. 2006, 28, 63-80. [CrossRef]

12. Cervellati, M.; Sunde, U.; Zimmermann, K.F. Demographic dynamics and long-run development: Insights for the secular stagnation debate. J. Popul. Econ. 2017, 30, 401-432. [CrossRef]

13. Zambon, I.; Serra, P.; Sauri, D.; Carlucci, M.; Salvati, L. Beyond the 'Mediterranean City': Socioeconomic Disparities and Urban Sprawl in three Southern European Cities. Geogr. Ann. B 2017, 99, 319-337. [CrossRef]

14. Forster, $\mathrm{C}$. The challenge of change: Australian cities and urban planning in the new millennium. Geogr. Res. 2006, 44, 173-182. [CrossRef]

15. Dyson, T. The role of the demographic transition in the process of urbanization. Popul. Dev. Rev. 2011, 37, 34-54. [CrossRef] [PubMed]

16. Davis, D.E. Reflections on the relations between development and urbanization: Past trajectories and future challenges. Int. J. Urban Sci. 2016, 20, 1-14. [CrossRef]

17. Matanle, P.; Sato, Y. Coming soon to a city near you! Learning to live 'beyond growth' in Japan's shrinking regions. Soc. Sci. Jpn. J. 2010, 13, 187-210. [CrossRef]

18. Kabisch, N.; Haase, D. Diversifying European agglomerations: Evidence of urban population trends for the 21st century. Popul. Space Place 2011, 17, 236-253. [CrossRef]

19. Lerch, M. The Role of Migration in the Urban Transition: A Demonstration from Albania. Demography 2014, 51, 1527-1550. [CrossRef]

20. Munafò, M.; Salvati, L.; Zitti, M. Estimating soil sealing at country scale-Italy as a case study. Ecol. Indic. 2013, 26, 36-43. [CrossRef] 
21. Colantoni, A.; Grigoriadis, E.; Sateriano, A.; Venanzoni, G.; Salvati, L. Cities as selective land predators? A Lesson on Urban Growth, (Un)effective planning and Sprawl Containment. Sci. Total Environ. 2016, 545-546, 329-339. [CrossRef] [PubMed]

22. Cuadrado-Ciuraneta, S.; Durà-Guimerà, A.; Salvati, L. Not only tourism: Unravelling suburbanization, second-home expansion and "rural" sprawl in Catalonia, Spain. Urban Geogr. 2017, 38, 66-89. [CrossRef]

23. Montgomery, M.R. The urban transformation of the developing world. Science 2008, 319, 761-764. [CrossRef] [PubMed]

24. Porter, J.R.; Howell, F.M. On the 'Urbanness' of Metropolitan Areas: Testing the Homogeneity Assumption, 1970-2000. Popul. Res. Policy Rev. 2009, 28, 589-601. [CrossRef]

25. Kroll, F.; Kabisch, N. The Relation of Diverging Urban Growth Processes and Demographic Change along an Urban-Rural Gradient. Popul. Space Place 2012, 18, 260-276. [CrossRef]

26. Rogers, A. Sources of urban population growth and urbanization, 1950-2000: A demographic accounting. Econ. Dev. Cult. Chang. 1982, 30, 483-506. [CrossRef]

27. Sharma, S. Persistence and stability in city growth. J. Urban Econ. 2003, 53, 300-320. [CrossRef]

28. Soo, K.T. Zipf's Law and urban growth in Malaysia. Urban Stud. 2007, 44, 1-14. [CrossRef]

29. Seto, K.C.; Fragkias, M.; Güneralp, B.; Reilly, M.K. A meta-analysis of global urban land expansion. PLoS ONE 2011, 6, e23777. [CrossRef]

30. Sato, Y.; Yamamoto, K. Population concentration, urbanization, and demographic transition. J. Urban Econ. 2005, 58, 45-61. [CrossRef]

31. Sobotka, T.; Skirbekk, V.; Philipov, D. Economic Recession and Fertility in the Developed World. Popul. Dev. Rev. 2011, 37, 267-306. [CrossRef] [PubMed]

32. Rees, P.; van der Gaag, N.; de Beer, J.; Heins, F. European regional populations: Current trends, future pathways, and policy options. Eur. J. Popul. 2012, 28, 385-416. [CrossRef] [PubMed]

33. Guérin-Pace, F. Rank-size distribution and the process of urban growth. Urban Stud. 1995, 32, 551-562. [CrossRef]

34. Carlucci, M.; Grigoriadis, E.; Rontos, K.; Salvati, L. Revisiting an Hegemonic Concept: Long-term ‘Mediterranean Urbanization' in between city re-polarization and metropolitan decline. Appl. Spat. Anal. Policy 2017, 10, 347-362. [CrossRef]

35. Glaeser, E.L.; Shapiro, J.M. Urban growth in the 1990s: Is city living back? J. Reg. Sci. 2003, 43, $139-165$. [CrossRef]

36. Fuguitt, G.V.; Beale, C.L. Population trends of nonmetropolitan cities and villages in sub-regions of the United States. Demography 1978, 15, 605-620. [CrossRef]

37. Jones, G.W. Southeast Asian urbanization and the growth of mega-urban regions. J. Popul. Res. 2002, 19, 119-136. [CrossRef]

38. Martinez-Fernandez, C.; Audirac, I.; Fol, S.; Cunningham-Sabot, E. Shrinking cities: Urban challenges of globalization. Int. J. Urban Reg. Res. 2012, 36, 213-225. [CrossRef]

39. Kourtit, K.; Nijkamp, P. In praise of megacities in a global world. Reg. Sci. Policy Pract. 2013, 5, 167-182. [CrossRef]

40. Weber, H.; Sciubba, J.D. The Effect of Population Growth on the Environment: Evidence from European Regions. Eur. J. Popul. 2018, 35, 379-402. [CrossRef]

41. González-Val, R.; Lanaspa, L.; Sanz-Gracia, F. New evidence on Gibrat's law for cities. Urban Stud. 2014, 51, 93-115. [CrossRef]

42. McCann, P. Urban futures, population ageing and demographic decline. Camb. J. Reg. Econ. Soc. 2017, 10, 543-557. [CrossRef]

43. Haase, A.; Bernt, M.; Großmann, K.; Mykhnenko, V.; Rink, D. Varieties of shrinkage in European cities. Eur. Urban Reg. Stud. 2016, 23, 86-102. [CrossRef]

44. Reher, D.S. Economic and Social Implications of the Demographic Transition. Popul. Dev. Rev. 2011, 37 (Suppl. 1), 11-33. [CrossRef]

45. United Nations, Department of Economic and Social Affairs, Population Division. World Urbanization Prospects: The 2014 Revision, CD-ROM ed.; United Nations, Department of Economic and Social Affairs, Population Division: New York, NY, USA, 2014. 
46. Salvati, L.; Gargiulo Morelli, V. Unveiling Urban Sprawl in the Mediterranean Region: Towards a Latent Urban Transformation? Int. J. Urban Reg. Res. 2014, 38, 1935-1953. [CrossRef]

47. Fox, S. Urbanization as a global historical process: Theory and evidence from sub-Saharan Africa. Popul. Dev. Rev. 2012, 38, 285-310. [CrossRef]

48. Biasi, R.; Colantoni, A.; Ferrara, C.; Ranalli, F.; Salvati, L. In-between sprawl and fires: Long-term forest expansion and settlement dynamics at the wildland-urban interface in Rome, Italy. Int. J. Sustain. Dev. World Ecol. 2015, 22, 467-475. [CrossRef]

49. Rontos, K.; Grigoriadis, S.; Sateriano, A.; Syrmali, M.; Vavouras, I.; Salvati, L. Lost in Protest, Found in Segregation: Divided Cities in the Light of the 2015 'Oki' Referendum in Greece. City Cult. Soc. 2016, 7, 139-148. [CrossRef]

50. Duvernoy, I.; Zambon, I.; Sateriano, A.; Salvati, L. Pictures from the Other Side of the Fringe: Urban Growth and Peri-urban Agriculture in a Post-industrial City (Toulouse, France). J. Rural Stud. 2018, 57, 25-35. [CrossRef]

51. Buettner, T. Urban estimates and projections at the United Nations: The strengths, weaknesses, and underpinnings of the world urbanization prospects. Spat. Demogr. 2015, 3, 91-108. [CrossRef]

52. Jiang, L. Internal consistency of demographic assumptions in the shared socioeconomic pathways. Popul. Environ. 2014, 35, 261-285. [CrossRef] [PubMed]

53. Di Feliciantonio, C.; Salvati, L. 'Southern' alternatives of urban diffusion: Investigating settlement characteristics and socioeconomic patterns in three Mediterranean regions. Tijdschr. Econ. Soc. Geogr. 2015, 106, 453-470. [CrossRef]

54. Jiang, L.; O'Neill, B.C. Global urbanization projections for the Shared Socioeconomic Pathways. Glob. Environ. Chang. 2017, 42, 193-199. [CrossRef]

55. Carbonaro, G.; Leanza, E.; McCann, P.; Medda, F. Demographic decline, population aging, and modern financial approaches to urban policy. Int. Reg. Sci. Rev. 2018, 41, 210-232. [CrossRef]

56. Billari, F.; Kohler, H.P. Patterns of low and lowest-low fertility in Europe. Popul. Stud. 2004, 58, 161-176. [CrossRef] [PubMed]

57. Ferrara, C.; Carlucci, M.; Grigoriadis, E.; Corona, P.; Salvati, L. A comprehensive insight into the geography of forest cover in Italy: Exploring the importance of socioeconomic local contexts. For. Policy Econ. 2017, 75, 12-22. [CrossRef]

58. Serra, P.; Vera, A.; Tulla, A.F.; Salvati, L. Beyond urban-rural dichotomy: Exploring socioeconomic and land-use processes of change in Spain (1991-2011). Appl. Geogr. 2014, 55, 71-81. [CrossRef]

59. Salvati, L.; Serra, P. Estimating rapidity of change in complex urban systems: A multidimensional, local-scale approach. Geogr. Anal. 2016, 48, 132-156. [CrossRef]

60. Pili, S.; Grigoriadis, E.; Carlucci, M.; Clemente, M.; Salvati, L. Towards Sustainable Growth? A Multi-criteria Assessment of (Changing) Urban Forms. Ecol. Indic. 2017, 76, 71-80. [CrossRef]

61. Galor, O.; Weil, D.N. Population, technology, and growth: From Malthusian stagnation to the demographic transition and beyond. Am. Econ. Rev. 2000, 90, 806-828. [CrossRef]

62. O'Neill, B.C.; Dalton, M.; Fuchs, R.; Jiang, L.; Pachauri, S.; Zigova, K. Global demographic trends and future carbon emissions. Proc. Natl. Acad. Sci. USA 2010, 107, 17521-17526. [CrossRef] [PubMed]

63. Salvati, L.; Gargiulo, V.; Rontos, K.; Sabbi, A. Latent Exurban Development: City Expansion along the Rural-To-Urban Gradient in Growing and Declining Regions of Southern Europe. Urban Geogr. 2013, 34, 376-394. [CrossRef]

64. Dijkstra, L.; Garcilazo, E.; McCann, P. The effects of the global financial crisis on European regions and cities. J. Econ. Geogr. 2015, 15, 935-949. [CrossRef]

65. Cottineau, C. A multilevel portrait of shrinking urban Russia. Espace Popul. Soc. 2016. Available online: http://journals.openedition.org/eps/6123 (accessed on 10 January 2020). [CrossRef]

66. Li, H.; Mykhnenko, V. Urban shrinkage with Chinese characteristics. Geogr. J. 2018, 184, 398-412. [CrossRef]

67. Warnes, A.; Williams, A. Older Migrants in Europe: A New Focus for Migration Studies. J. Ethn. Migr. Stud. 2006, 32, 1257-1281. [CrossRef]

68. Morelli, V.G.; Rontos, K.; Salvati, L. Between suburbanisation and re-urbanisation: Revisiting the urban life cycle in a Mediterranean compact city. Urban Res. Pract. 2014, 7, 74-88. [CrossRef] 
69. Salvati, L.; Zambon, I.; Chelli, F.M.; Serra, P. Do spatial patterns of urbanization and land consumption reflect different socioeconomic contexts in Europe? Sci. Total Environ. 2018, 625, 722-730. [CrossRef]

70. Zambon, I.; Benedetti, A.; Ferrara, C.; Salvati, L. Soil matters? A multivariate analysis of socioeconomic constraints to urban expansion in Mediterranean Europe. Ecol. Econ. 2018, 146, 173-183. [CrossRef]

(C) 2020 by the authors. Licensee MDPI, Basel, Switzerland. This article is an open access article distributed under the terms and conditions of the Creative Commons Attribution (CC BY) license (http://creativecommons.org/licenses/by/4.0/). 